\title{
Reduction in Occurrence Frequency of Albinism in Juvenile Flounder Paralichthys olivaceus Hatchery-reared on Wild Zooplankton*1
}

\author{
Tadahisa SEIKAI ${ }^{* 2}$ \\ (Accepted January 18, 1985)
}

\begin{abstract}
The effect of a wild zooplankton supply on the appearance of albinism in juvenile flounder $P$. olivaceus was studied by two rearing experiments. Flounder larvae were initially reared with only rotifer Brachionus plicatilis and then given wild zooplankton and rotifer or only wild zooplankton, from $5.50-5.57 \mathrm{~mm}$ TL to complete metamorphosis. These were compared with those given Brazilian Artemia salina nauplii and rotifer during the same stage. Larvae given wild zooplankton showed poorer growth and lower survival rate than those given Artemia. However the frequency occurrence of albinism in the former was very much lower $(0.1-1.8 \%)$ than in the latter $(97.2-$ $100.0 \%$. When flounder larvae were given wild zooplankton and rotifer, they took $40.0-76.3 \%$ rotifer in number during pelagic stage, These results suggested the possibility of preventing albinism through the improvement of cultured foods during early life stage.
\end{abstract}

Juvenile hatchery-reared flounder $P$. olivaceus showed high occurrence frequency (more than $97 \%$ of albinism when they began to be fed on Brazilian Artemia salina nauplii from the earlier stage less than $10.0 \mathrm{~mm}$ TL. ${ }^{1)}$ This result might suggest a close relationship between the appearence of albinism and larval diet, and a possibility to prevent occurrence of albinism in hatchery-reared heterosomata through dietary improvement. In this study, flounder larvae were reared on wild zooplankton which might have similar nutritional constituents to the wild larval food, and the infiuence of this diet on the appearance of albinism of juvenile flounder was studied.

\section{Materials and Methods}

\section{Proceeding of Rearing Experiments}

Two rearing experiments, Expts. 1 and 2, were carried out from May 8 to June 22, 1982 in the Fisheries Research Station, Kyoto University. One hundred $l$ polycarbonate tanks $(\phi 51 \mathrm{~cm} \times$ $50 \mathrm{~cm}$ depth) were used for the experiments, and $500 l$ polycarbonate tanks $(\phi 100 \mathrm{~cm} \times 70 \mathrm{~cm}$ depth) were used for preliminary rearing. Flounder eggs were fertilized artificially without hormone injection from wild parents caught by longline and reared in captivity for about one month at the Kyoto Institute of Oceanic and Fishery Science, Miyazu. Prepared larvae for Exp. 1 were first reared for 10 days post-hatching $(5.57 \mathrm{~mm} \mathrm{TL})$ in a preliminary rearing tank exclusively with rotifer Branchionus plicatilis. Two experimental tanks for Exp. 1 (Tank 1-WZ1 and 1-WZ2) held 850 larvae (10 days post-hatching) each. Two control tanks for Exp. 1 (Tank 1-C1 and 1-C2: the same size as experimental tanks) held 1,000 larvae each. Wild zooplankton and rotifer were given to larvae in the experimental tanks. Brazilian Artemia nauplii and rotifer were given to larvae in the control tanks as the same way in another study. ${ }^{\text {s }}$ The daily amount and the composition of wild zooplankton given to each experimental tank varied due to their harvests (Fig. 1 and Table 1). The daily amount of rotifer given to larvae was maintained at $50 \times 10^{4}$ ind./tank as L-rotifer. Majority of larvae for Exp. 2 were first reared for 9-10 days post-hatching ( $5.50 \mathrm{~mm}$ TL) in two preliminary rearing tanks exclusively with rotifer. After 4-5 days post-hatching, 750 larvae each from the two tanks removed into one experimental tank (Tank 2-WZ1'), and given rotifer and wild zooplankton for 6 days after then. One of two experimental tanks (Tank 2-WZ1) held 1,000 larvae from 1,050 survivors $(5.51 \mathrm{~mm}$ TL) of Tank 2-WZ1', and another (Tank 2-WZ2) held 1,000 larvae from two preliminary rearing tanks. Larvae in Tank 2-WZ1 were given only wild zooplankton and larvae in Tank $2-W Z 2$ were given wild zooplankton and rotifer as the same way in Exp. 1.

*1 Orally presented at the annual meeting of the Japan. Soc. Sci. Fish., in April, 1983 (Tokyo).

*2 Fisheries Research Station, Faculty of Agriculture, Kyoto University, Maizuru, Kyoto 625, Japan (青海 忠久: 京都大学農学部付属水産実験所). 


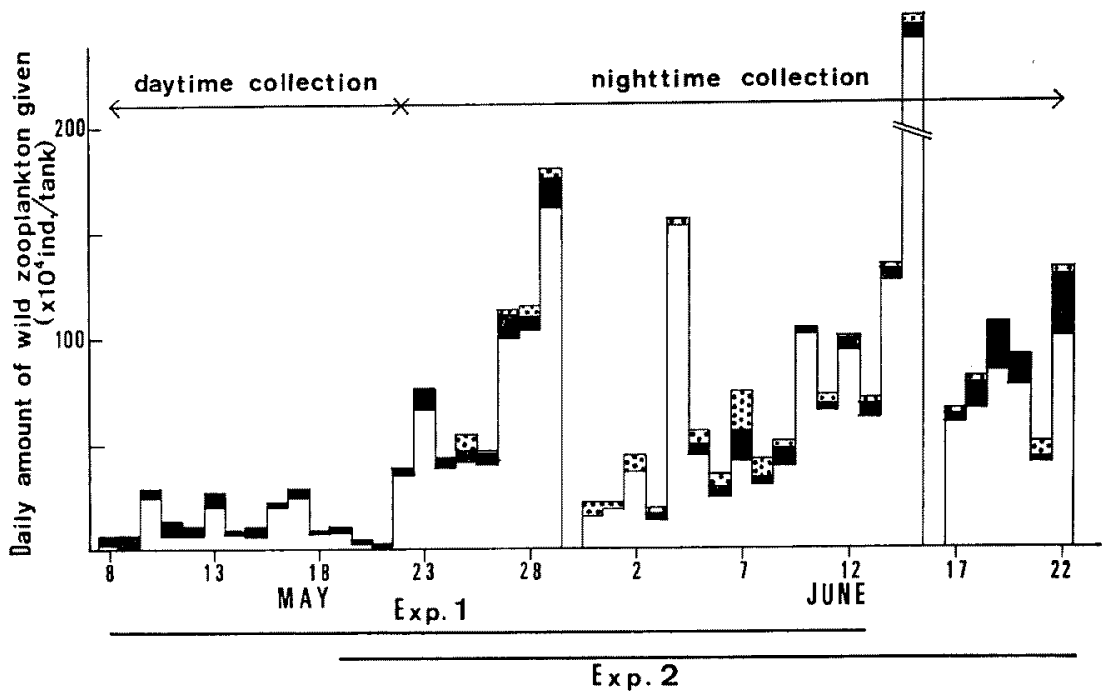

Fig. 1. Daily amount of wild zooplankton given to larvae in each experimental tank. $\square$ : copepod adult, ... cladocera, $\square$; others.

Table 1. Change of wild zooplankton compositions given to larval flounder, $P$, olivaceus ( $\%)$

\begin{tabular}{|c|c|c|c|c|c|c|c|c|c|c|c|c|}
\hline \multirow{2}{*}{ Date } & \multicolumn{8}{|c|}{ May } & \multicolumn{4}{|c|}{ June } \\
\hline & 9 & 11 & 14 & 16 & 22 & 26 & 29 & 30 & 6 & 8 & 17 & 22 \\
\hline Podon spp. & 55.6 & 42.2 & 22.7 & 4.0 & 7.5 & 4.7 & 16.3 & 17.7 & 7.8 & 6.1 & 1.8 & 4.0 \\
\hline Evadne nordmanni & 5.3 & 0.7 & 1.7 & 0.8 & - & 一 & - & - & 2.9 & - & 5.5 & 2.3 \\
\hline Penilia avirostris & tr. & - & - & - & - & - & - & 2.9 & 1.0 & 1.1 & 3.6 & 23.9 \\
\hline Oithona brevicornis & 20.3 * & 40.3 & 37.0 & 75.2 & 59.9 & 41.9 & 60.0 & 67.6 & 34.9 & 44.4 & 61.8 & 55.7 \\
\hline Oithona similis & 0.8 & 0.7 & 3.4 & 3.2 & 1.1 & - & 1.3 & - & tr. & - & - & - \\
\hline Paracalanus crasrostris & 0.8 & 1.4 & 5.9 & 0.8 & 2.1 & 2.3 & 2.5 & - & 2.9 & 11.1 & 3.6 & 2.3 \\
\hline Acartia clausi & 1.5 & tr. & 5.0 & 2.4 & 1.1 & 6.9 & 3.8 & 5.9 & 2.9 & 7.0 & 1.8 & 4.0 \\
\hline Centropages sp. & - & 1.2 & 1.7 & - & - & - & 1.6 & - & 1.4 & - & tr. & tr. \\
\hline Corycaeus affinis & - & - & - & - & 3.2 & 9.3 & 1.3 & - & 1.0 & - & - & - \\
\hline Microsetella novegica & 3.0 & 2.0 & 2.5 & 1.6 & 2.1 & - & - & - & - & 2.0 & - & 0.6 \\
\hline Copepod nauplii & 6.8 & 11.4 & 15.1 & 11.2 & 12.9 & 23.3 & 5.0 & 5.9 & 26.2 & - & 3.6 & 0.6 \\
\hline Balanus naupliii & tr. & tr. & 2.5 & tr. & 1.1 & 9.3 & 5.0 & - & 15.5 & 21.2 & 5.5 & 3.4 \\
\hline Brachyura zoea & - & - & 0.8 & - & - & - & - & - & 1.0 & 3.0 & 5.5 & - \\
\hline Decapoda mysis & - & 一 & 0.8 & - & - & - & - & - & - & 2.0 & - & 0.6 \\
\hline Polychaeta larvae & - & 一 & - & - & - & - & - & - & 2.9 & - & 3.6 & 1.1 \\
\hline Cyttarocylidae sp. & 5.2 & 10.7 & 0.8 & 0.8 & 8.1 & 2.3 & 2.5 & - & - & - & - & - \\
\hline
\end{tabular}

At the same time larvae in two control tanks (Tank 2-C1 and 2-C2) which held 1,000 larvae each, were given Brazilian Artemia nauplii and rotifer as the same way in Exp. 1. Two strains of rotifer which were cultured with Chlorella $\mathrm{sp}$, and $\omega$-yeast ${ }^{2)}$ were used in this study. One was $\mathbf{L}$ rotifer (Lorica length: about $250 \mu \mathrm{m}$ ) which was adaptive to low culture temperature between 18 and $20^{\circ} \mathrm{C}$, and was used during the anterior part of the experiments. Another was S-rotifer (Lorica length about $120-150 \mu \mathrm{m}$ ) which was adaptive to high culture temperature between 25 and $27^{\circ} \mathrm{C}$, and was used while L-rotifer could not be used. Daily amount of S-rotifer given to larvae was two times more than that of L-rotifer from its individual weight. Other conditions for the rearing experiments used in this study were the same as used for another study. ${ }^{1)}$

\section{Wild Zooplankton Given to Larvae}

Wild zooplankton were collected by filtering sea water through a $21 \mathrm{NXX}$ nylon net (opening 
$71 \mu \mathrm{m})$. The collections were carried out in the daytime from May 8 to May 22, and in the nighttime from May 23 to June 22 with aid of the fish attracting lamp. Sea water was pumped up from a depth of $5 \mathrm{~m}$ by a submerged pump (flow rate; $5,000 \mathrm{l} / \mathrm{h}$ ), which was suspended from the observation pontoon at the Fisheries Research Station, Kyoto University. Collected plankton were given to larvae after removing large polychaeta, juveniles of Engraulis japonica and debris. The major parts of wild zooplankton given to larvae were first copepoda (Oithona brevicornis and 6 other species) second cladocera (Podon spp. and 3 other species) and then copepod and Balanus nauplii (Table 1).

\section{Sampling and Measurement of Larvae}

Sampling and measurement of larvae during experiments, harvesting at the end of experiments, and classification of albinism were carried out by the same way in another study. ${ }^{1)}$ Total length (straight-line distance from anteriormost part of head to tip of tail) was used for measurement of living larvae. Body length (for larvae straight-line distance from tip of snout to posterior tip of notchord and for juveniles straight-line distance from tip of snout to end of hypural elements) was used for measurement of preserved larvae be- cause the limb of finforld was deformed easily by fixation.

\section{Investigation of Gut Contents}

Since larvae in Tank 1-WZ1 and 1-WZ2 were given rotifer in addition to wild zooplankton, their gut contents were examined to reveal the influence of the natural diet. The larvae and juveniles taken out every several days from Tank 1-WZ1 and $1-\mathrm{WZ} 2$ were preserved in $5 \%$ neutralized formalin. After about five months, the species and numbers of food items in their guts were examined. In this study, the term "gut" is digestive organ from the oesophagus to the rectum. The composition and individual numbers of gut contents were summerized relating to body length.

\section{Results}

\section{Outline of Rearing}

The larvae given wild zooplankton in the experimental tanks showed poorer growth and lower survival rate than those given Artemia in the control tanks in all cases, (Table 2 and Fig. 2). For example, at the end of experiments, mean TL for larvae of the experimental tanks (and of the control tanks) were $12.7-13.2 \mathrm{~mm}(18.3-18.7 \mathrm{~mm})$ in

Table 2. Outline of rearing experiments (Expts. 1 and 2) of larval flounder, $P$. olivaceus, given wild zooplankton and rotifer (Tank 1-WZ1, 1-WZ2 and 2-WZ2), wild zooplankton only (Tank 2-WZ1) and Brazilian Artemia and rotifer (Tank 1-C1, 1-C2, 2-C1 and 2-C2)

\begin{tabular}{|c|c|c|c|c|c|c|c|c|c|}
\hline & \multirow{2}{*}{$\begin{array}{l}\text { Expts. } \\
\text { Tank }\end{array}$} & \multicolumn{4}{|c|}{ Exp. 1} & \multicolumn{4}{|c|}{ Exp. 2} \\
\hline & & 1-WZ1 & 1-WZ2 & $1-\mathrm{C} 1$ & $1-\mathrm{C} 2$ & 2-WZ1 & 2-WZ2 & $2-\mathrm{Cl}$ & $2-\mathrm{C} 2$ \\
\hline \multicolumn{2}{|l|}{ Diet } & \multicolumn{2}{|c|}{$\mathrm{WZ}^{* 1}+\mathrm{R}^{* 2}$} & \multicolumn{2}{|c|}{$\mathrm{BA}^{* 3}+\mathrm{R}$} & $\mathrm{WZ}$ & $\mathrm{WZ}+\mathrm{R}$ & \multicolumn{2}{|c|}{$\mathrm{BA}+\mathrm{R}$} \\
\hline \multicolumn{10}{|c|}{ Initial larvae } \\
\hline \multicolumn{2}{|c|}{ Number $\left(\mathbf{N}_{0}\right)$} & \multicolumn{2}{|c|}{850} & \multicolumn{2}{|c|}{1,000} & 1,000 & 1,000 & \multicolumn{2}{|c|}{1,000} \\
\hline \multirow[t]{2}{*}{$\mathrm{TL}(\mathrm{mn}$} & m) Mean & \multicolumn{4}{|c|}{5.57} & 5.51 & 5.50 & \multicolumn{2}{|c|}{5.50} \\
\hline & S.D. & \multicolumn{4}{|c|}{0.33} & 0.34 & 0.32 & \multicolumn{2}{|c|}{0.32} \\
\hline \multicolumn{2}{|c|}{ Days post-hatching } & \multicolumn{4}{|c|}{10} & $9+10$ & $9+10$ & \multicolumn{2}{|c|}{$9+10$} \\
\hline \multicolumn{2}{|c|}{$\begin{array}{l}\text { No. of specimens taken } \\
\text { out during expts. }\left(\mathbf{N}_{1}\right)\end{array}$} & \multicolumn{4}{|c|}{200} & 120 & 200 & \multicolumn{2}{|c|}{200} \\
\hline \multicolumn{10}{|c|}{ Survivors at the end of expts. } \\
\hline \multicolumn{2}{|c|}{ Number $\left(\mathrm{N}_{2}\right)$} & 238 & 105 & 608 & 645 & 54 & 248 & 621 & 552 \\
\hline \multirow[t]{2}{*}{$\mathrm{TL}(\mathrm{mn}$} & m) Mean & 13.5 & 12.7 & 18.7 & 18.3 & 15.4 & 16.3 & 17.2 & 16.6 \\
\hline & S.D. & 1.5 & 1.3 & 2.3 & 2.2 & 4.0 & 2.8 & 2.5 & 2.5 \\
\hline Duration & of expts. (days) & 36 & 36 & 30 & 30 & 35 & 35 & 27 & 27 \\
\hline \multicolumn{10}{|c|}{ Survival rate $(\%)$} \\
\hline \multirow{2}{*}{\multicolumn{2}{|c|}{$\begin{array}{l}\mathrm{N}_{2} /\left(\mathrm{N}_{0}-\mathrm{N}_{1}\right) 100 \\
\text { No. of metamorphosed fish }\end{array}$}} & 36.6 & 16.2 & 76.0 & 80.1 & 6.1 & 31.0 & 77.6 & 69.0 \\
\hline & & 223 & 94 & 606 & 645 & 45 & 247 & 621 & 652 \\
\hline $\begin{array}{ll}* 1 & \text { WZ: } \\
* 2 & \text { R: } \\
* 3 & \text { BA: }\end{array}$ & $\begin{array}{l}\text { Id zooplankton } \\
\text { tifer cultured with Chl } \\
\text { zzilian Artemia salina }\end{array}$ & sp. an & & & & & & & \\
\hline
\end{tabular}




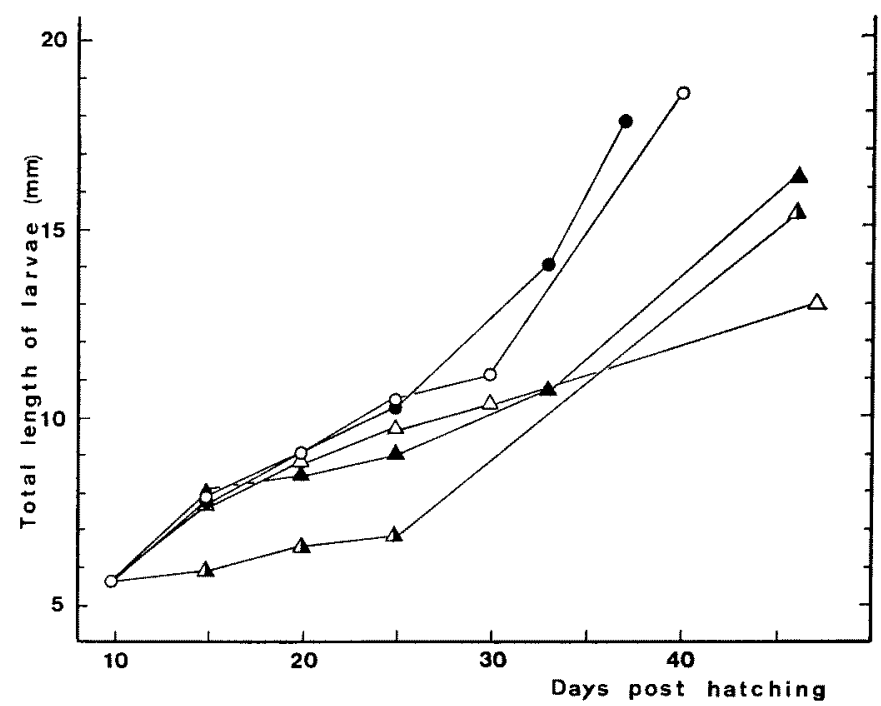

Fig. 2. Mean larval growth of experimental and control tanks in Expts. 1 and 2. $\triangle$ : larvae in 1-WZ1 and 1-WZ2 tanks which were given wild zooplankton and rotifer. $0:$ larvae in 1-C1 and 1-C2 tanks which were given Artemia nauplii and rotifer. $\Delta:$ larvae in 2-WZ1 which were given wild zooplankton only. $\Delta$ : larvae in $2-W Z 2$ tanks which were given wild zooplankton and rotifer. $\quad$ : larvae in 2-Cl and 2-C2 tanks which were given Artemia nauplii and rotifer.

Table 3. Compositions of gut contents of each size of larval flounder, $P$. olivaceus, given wild zooplankton and rotifer in Exp. 1

\begin{tabular}{|c|c|c|c|c|c|c|c|}
\hline Body length (mm) & $6.0-6.9$ & $7.0-7.9$ & $8.0-8.9$ & $9.0-9.9$ & $10.0-10.9$ & $11.0-11.9$ & 12.0 \\
\hline \multicolumn{8}{|l|}{ Sampling date } \\
\hline May 13 & 4 & 6 & - & - & - & - & - \\
\hline 18 & - & 7 & 3 & - & - & - & - \\
\hline \multirow[t]{4}{*}{ No. of specimens } & - & 2 & 8 & - & - & - & - \\
\hline & - & 2 & 5 & 3 & - & - & - \\
\hline & - & - & 5 & 9 & 10 & 10 & 12 \\
\hline & 4 & 17 & 21 & 12 & 10 & 10 & 12 \\
\hline \multicolumn{8}{|l|}{ Food items $(\%)$} \\
\hline Brachionus plicatilis & 64.8 & 76.3 & 52.9 & 40.0 & 0.3 & 1.0 & 1.1 \\
\hline Podon spp. & 3.4 & 5.6 & 1.9 & 1.1 & 0.3 & 1.4 & 1.7 \\
\hline Evadne nordmanni & - & - & 2.3 & 4.5 & 12.5 & 32.2 & 8.5 \\
\hline Penilia avirostris & - & - & 0.3 & 0.4 & - & 0.6 & 0.6 \\
\hline Oithona brevicornis & 29.5 & 15.9 & 32.8 & 32.9 & 4.2 & 4.9 & 2.6 \\
\hline Acartia clausi & - & 0.7 & 4.0 & 9.6 & 14.2 & 10.7 & 6.6 \\
\hline Paracalanus crasrostris & - & 0.4 & 1.3 & 7.2 & 49.5 & 34.0 & 21.3 \\
\hline Corycaeus affinis & - & - & 0.8 & 0.5 & 0.3 & - & 0.2 \\
\hline Mycrosetella norvegica & 1.1 & - & 0.8 & - & 0.3 & 一 & 0.2 \\
\hline Copepod nauplii & - & 0.3 & 1.8 & - & 0.3 & - & - \\
\hline Balanus nauplii & - & 0.7 & 0.8 & 0.2 & - & - & 0.2 \\
\hline Brachiura zoea & - & - & - & 0.2 & - & - & 0.2 \\
\hline Decapoda mysis & - & - & - & 2.9 & 17.3 & 14.6 & 56.4 \\
\hline Ceratium sp. & 1.1 & 一 & - & 0.2 & - & - & - \\
\hline Cyttarocylidae $\mathrm{sp}$. & - & 0.1 & 0.3 & 0.1 & - & - & - \\
\hline Polychaeta larvae & - & - & - & 0.1 & 0.3 & - & - \\
\hline No. of food/larval gut & 22.0 & 48.9 & 42.3 & 81.5 & 28.9 & 48.5 & 44.2 \\
\hline No, of food items & 5 & 8 & 12 & 14 & 11 & 8 & 12 \\
\hline
\end{tabular}


Table 4. Occurrence frequency of each colored type individual and pigment index* by each experimtnal and control tank of Expts. 1 and 2

\begin{tabular}{|c|c|c|c|c|c|c|c|c|c|}
\hline \multirow{2}{*}{$\begin{array}{c}\text { Expts. } \\
\text { Tank }\end{array}$} & & \multicolumn{4}{|c|}{ Exp. 1} & \multicolumn{4}{|c|}{ Exp. 2} \\
\hline & & 1-WZ1 & $1-W Z 2$ & 1-C1 & $1-\mathrm{C} 2$ & 2-WZ1 & 2-WZ2 & $2-\mathrm{Cl}$ & $2-\mathrm{C} 2$ \\
\hline \multirow{17}{*}{ 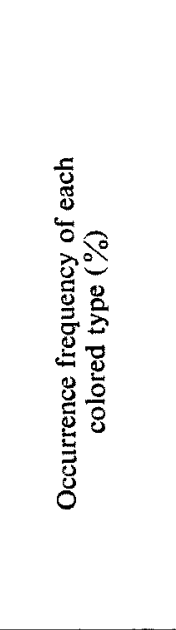 } & Normal & 98.2 & 100.0 & 3.0 & 2.7 & 100.0 & 98.8 & 0.5 & - \\
\hline & Albinism & & & & & & & & \\
\hline & I & 1.8 & - & 29.2 & 19.5 & - & 0.8 & 57.9 & 61.1 \\
\hline & II & - & - & 11.9 & 12.0 & - & - & 2.1 & - \\
\hline & IIIi & - & - & 2.0 & 3.3 & - & 0.4 & 0.9 & 10.4 \\
\hline & IV & - & - & 0.5 & 1.1 & - & - & - & - \\
\hline & V & - & - & - & - & - & - & - & - \\
\hline & VI & - & - & 1.5 & 0.6 & - & - & 一 & - \\
\hline & VII & - & - & - & 0.2 & - & - & - & - \\
\hline & VIII & - & - & 1.7 & 3.0 & 一 & - & - & - \\
\hline & $\mathrm{II}+\mathrm{III}$ & - & - & 22.0 & 27.2 & - & - & 18.6 & 21.1 \\
\hline & $\mathrm{II}+\mathrm{IV}$ & - & - & 4.6 & 3.3 & - & - & 11.0 & 7.4 \\
\hline & $\mathrm{V}+\mathrm{VI}$ & - & - & 7.8 & 8.6 & - & - & - & - \\
\hline & $\mathrm{V}+\mathrm{VIII}$ & - & - & 0.5 & 1.7 & - & 一 & - & - \\
\hline & $\mathrm{VII}+\mathrm{VIII}$ & - & - & 0.7 & 1.4 & - & - & - & - \\
\hline & $\mathrm{V}+\mathrm{VI}+\mathrm{VII}$ & - & - & 14.9 & 15.6 & - & - & 一 & - \\
\hline & Subtotal & 1.8 & - & 97.0 & 97.3 & - & 0.8 & 99.5 & 100.0 \\
\hline Pigment index & & 98.2 & 100.0 & 31.5 & 35.3 & 100.0 & 98.8 & 11.0 & 10.1 \\
\hline
\end{tabular}

Exp. 1, and 15.4-16.3 mm (16.6-17.2 mm) in Exp. 2. Survival rates for larvae of the experimental tanks (and of the control tanks) were 16.2-36.6\% $(76.0-80.1 \%)$ in Exp. 1, 6.1-31.0\% (69.0-77.6\%) in Exp. 2. The minimum size of completely metamorphosized fish in the experimental tanks (12.5 $\mathrm{mm} \mathrm{TL}: 10.0 \mathrm{~mm} \mathrm{BL}$ ) was smaller than that in the control tanks (14.5 mm TL: $11.6 \mathrm{~mm} \mathrm{BL).}$

\section{Larval Feeding of Wild Zooplankton}

The gut contents of larvae from the experimental tank in Exp. 1 showed some variation on the intake of each food with growth (Table 3). Developmental stages could be devided into two major stages according to the gut content composition, corresponding to $6.0-9.9 \mathrm{~mm} \mathrm{BL}$ (1st stage) and over $10.0 \mathrm{~mm} \mathrm{BL}$ (2nd stage). The first stage is pelagic larval stage and the second stage is benthic juvenile stage. On the 1st stage, rotifer was found most frequently in their guts $(40.0-76.3 \%)$. With the larval growth rotifer in their guts decreased gradually, and the flounder larvae began to eat various food items. A characteristic fact during the 1st stage was that very few Podon spp. and copepod nauplii were found in larval guts, as opposed to the relatively high percentages in the wild zooplankton given. On the 2nd stage, flounder juveniles reduced their intake of rotifer and Oithona brevicornis, and began to eat mainly cladocera (such as Evadne nordomanni), larger size copepods (Paracalanus crasrostris and Acartia clausi), and decapoda mysis. Their intake of decapoda mysis in guts increased remarkably on the 2 nd stage. During both 1 st and 2nd stages, very few Balanus nauplii were eaten, as opposed to the relatively high percentage occurrence on the food given.

\section{Occurrence Frequencies of Albinism}

Occurrence frequencies of albinic individuals from the experimental tanks were very low $(0.0$ $1.8 \%$ ) in both Expts. 1 and 2 (Table 4). Although the albinic juveniles from the experimental tanks were classified to type I and III (almost total albinism of trunk and tail). There were no significant differences on occurrence frequencies of albinism between wild zooplankton and rotifer complexed use (Tanks 1-ZW1, 1-WZ2 and 2-WZ2) and wild zooplankton only use (Tank 2-WZ1). On the other hand, occurrence frequencies of albinic individuals from the control tanks were very high (97.0-100.0\%) on both Expts. 1 and 2 . Although the occurrence frequency of each colored type in Exp. 1 differed from that in Exp. 2, the majority were the almost total albinism of trunk and tail. 


\section{Discussion}

Most fish larvae show the specific food preference. $^{3-5}$ So the presence of planktonic organisms does not necessarily mean that they are available as food to fish larvae. Wild larvae of flounder $P$. olivaceus changes their food from copepod nauplii to oicopleura and adult copepods with their growth. ${ }^{\theta, 7)}$ When they become juveniles they eat mainly mysids. ${ }^{7}$ ) On the tank reared flounder larvae given wild zooplankton, their gut contents showed that larvae changed their food from the smaller to the larger with their growth. While Oithona brevicornis which is seldom eaten by wild flounder larvae as opposed to its abundance in the larval habitat, ${ }^{\text {) }}$ was fed following rotifer. This result together with poorer growth and lower survival rate than those of larvae given Artemia presumes that their were deficient proper foods, such as Oicopleura longicoda, Evadne nordomanni, Paracalanus parvus which are popularly eaten by the wild larvae, ${ }^{8,7)}$ in their rearing tanks. On the juvenile stage, number of decapoda mysis in their guts increased remarkably, and this fact agreed well with the main intake of mysids on wild juveniles."

In this study, when flounder larvae took Brazilian Artemia and rotifer from $5.5 \mathrm{~mm}$ TL to completion of metamorphosis (14.5 mm TL), more than $97 \%$ of albicic individuals appeared. While flounder larvae were given wild zooplankton together with rotifer during the same stage, less than $1.8 \%$ of albinic individuals appeared. Wild zooplankton is composed of many species and exists in a complex marine ecosystem, while Artemia reproduces itself in a considerably specialized ecosystem of inland salt lake. Some constitutents which reflected the specifities of their havitat might introduce the different occurrence frequency of albinic juvenile flounder. Proxymate, mineral and amino acid composition of cultured food organisms (rotifer, Artemia, Tigriopus japonicus and others) are not so different from those of the wild zooplankton (copepods), ${ }^{8,0)}$ while fatty acid composition of the former is different remarkably from the latter. ${ }^{10)}$ On the case of albinism, the distinction of fatty acid composition may be negligible,* Albinism among heterosomata is usually of a partial character. ${ }^{11)}$ Together with this, the abnormality of scale form, ${ }^{112}$ early development of squamation ${ }^{12)}$ and nurvous control system observed in albinic portion of heterosomata ${ }^{13)}$ suggest that the albinic dermis of the ocular side resembles the white colored dermis of blind side. Chromatophore, scales and the end of automatic nervous system of fish exist in the dermal tissue. Chromatophore is induced in contact with the surrounding dermal and epidermal tissue. ${ }^{14}$ Although it is not revealed how the fish larvae complete their nervous control system over chromatophore, it is presumed that the fish larvae establish their color pattern in corporation with together nervous system and chromatophore. ${ }^{15)}$ If a dermal tissue of occular side differentiated partially to that of blind side during metamorphosis, dermal chromatophore may be induced to those of blind side, and this portion may be recognized as a albinic portion. Both a deficiency of essential materials and a inclusion of inhibitor may be responsible for such transdetermination in process of cytodifferentiation. It is not resolved whether defect or inhibition is relating to the occurrence of albinism among hatchery-reared heterosomata. The most effective method to prevent the appearence of albinism on juvenile flounder is that they are given wild zooplankton during larval stage. This is not so practical for mass culture of larval flounder because of the difficulty to collect the sufficient amount of wild zooplankton from sea. So further study is eargerly needed to reveal the consituents relating to albinism, and to improve the culture food (Artemia and rotifer).

\section{Acknowledgements}

I am very grateful to Prof. T. WATANaBe, Tokyo University of Fisheries, Prof. R. G. Ackman, Nova Scotia Technical College, and Dr. I. Nakamura, Kyoto University Fisheries Research Station for useful suggestions or critical reading of the manuscript. I also thank Dr. T. SHIokawa and other staff of Kyoto Institute of Oceanic and Fishery Science for technical assistance of rearing experiments, especially Dr. A. Kuwahara for identification of species of wild zooplankton. I would express my gratitude to Prof. S. FunTa, Tokyo University of Fisheries, and Dr. C. KrTAJIMA, Nagasaki Prefectural Institute of Fisheries for useful suggestions and encouragement.

\section{References}

1) T. SelkaI: Bull. Japan. Soc. Sci. Fish., 51, 521-

\footnotetext{
* Watanabe and SeikaI: unpublished data.
} 
527 (1985).

2) O. Imada, K. Kageyama, T. Watanabe, C. Kitajima, S. FujtTa, and Y. Yone: Bull. Japan. Soc. Sci. Fish., 45, 951-954 (1979), (in Japanese).

3) J. E. Shelbourn: J. Mar. Biol. Ass. U.K., 42, 243-252 (1962).

4) J. M. Last: Mar. Biol, , 48, 377-386 (1978).

5) J. M. LAst: J. Cons. Int. Explor. Mer., 25, 147157 (1979).

6) A. Kuwahara and S. Suzuki: Bull. Japan. Soc. Sci. Fish., 48, 1375-1381 (1982), (in Japanese).

7) T. Minami: Bull. Japan. Soc. Sci. Fish., 48, 1581-1588 (1982), (in Japanese).

8) T. Watanabe, T. Arakawa, C. Kitajima, K. Fukusho and S. Furrta: Bull. Japan. Soc. Sci. Fish., 44, 979-984 (1978), (in Japanese).

9) T. Watanabe, T. Arakawa, C. Kitajma, K. Fukusho, and S. Furta: Bull. Japan. Sci. Fish., 44, 985-988 (1978), (in Japanese).

10) T. Watanabe, T. Arakawa, C. Kitajima, K.
Fukusho, and S. Furta: Bull. Japan. Soc. Sci. Fish., 44, 1223-1227 (1978), (in Japanese).

11) J. R. Norman: A Systematic Monograph of the Flatfishes (Heterosomata), Vol. 1, Psetodidae, Bothidae, Preuronectidae, 1st ed., Brit. Mus., London, 1934, pp. 22-29.

12) T. SEIKaI: Japan. J. Ichthyol. 27, 249-255 (1980), (in Japanese).

13) K. Hanada and G. Fukushr: Aomori Kenritu Chyuou Byouin Ishi, 18(1), 6-11 (1973) (in Japanese).

14) H. IDE: in "Sikisosaibo-Kono Tokuina Shyuudan" (ed. by A. OIKAWA and H. IDE), 1st ed., Kodanshya, Tokyo, 1982, pp. 84-89, (in Japanese).

15) M. OBIKA: in "Sikisosaibo-Kono Tokuina Syuudan" (ed. by A. OrKaWA and H. IDE) 1st. ed., Kodanshya, Tokyo, 1982, pp. 47-50, (in Japanese). 